\title{
Article
}

\section{Two Advanced Cryogenic Procedures for Improving Stevia rebaudiana (Bertoni) Cryopreservation}

\author{
Carla Benelli ${ }^{1, *(D)}$, Lara S. O. Carvalho ${ }^{2}$, Soumaya EL merzougui ${ }^{3}$ and Raffaella Petruccelli $^{1}$ \\ 1 Institute of BioEconomy, National Research Council (CNR/IBE), 50019 Sesto Fiorentino, Florence, Italy; \\ raffaella.petruccelli@ibe.cnr.it \\ 2 Department of Biology, Federal University of Lavras, Lavras 3037, Brazil; lcarvalho470@gmail.com \\ 3 Laboratory of Biotechnology and Valorization of Natural Resources (LBVRN), Faculty of Sciences, \\ Ibn Zohr University, 8106 Agadir, Morocco; soumaya.merzougui@gmail.com \\ * Correspondence: carla.benelli@ibe.cnr.it
}

check for updates

Citation: Benelli, C.; Carvalho,

L.S.O.; EL merzougui, S.; Petruccelli,

R. Two Advanced Cryogenic

Procedures for Improving Stevia

rebaudiana (Bertoni) Cryopreservation.

Plants 2021, 10, 277. https://doi.

org/10.3390/plants10020277

Academic Editor: Gian-Pietro Di

Sansebastiano

Received: 29 December 2020

Accepted: 26 January 2021

Published: 31 January 2021

Publisher's Note: MDPI stays neutral with regard to jurisdictional claims in published maps and institutional affiliations.

Copyright: (c) 2021 by the authors. Licensee MDPI, Basel, Switzerland. This article is an open access article distributed under the terms and conditions of the Creative Commons Attribution (CC BY) license (https:// creativecommons.org/licenses/by/ $4.0 /)$.

\begin{abstract}
Cryopreservation is a useful tool for the long-term storage of plant genetic resources, and different cryogenic procedures have recently been developed. The present study focused on the use of the Droplet-vitrification (DV) and V cryo-plate protocol for the cryopreservation of Stevia rebaudianain vitro-derived apical shoot tips and axillary shoot tips. A preliminary test showed that 90 and $120 \mathrm{~min}$ PVS2 (Plant Vitrification Solution 2) treatment significantly reduced the regrowth of the explants before immersion in liquid nitrogen (LN). For both procedures tested, the best osmoprotective condition for obtaining a higher regrowth of cryopreserved explants occurred when explants were PVS2 treated for $60 \mathrm{~min}$. After direct immersion in LN, thawing and plating, the highest regrowth recorded was $80 \%$ with DV and $93 \%$ with V cryo-plate. Moreover, shoot tips proved to be a more suitable material for Stevia cryopreservation. A satisfactory vegetative regrowth was observed in the subcultures following cryopreservation by DV and V cryo-plate cryogenic procedures.
\end{abstract}

Keywords: apical shoot tips; axillary shoot tips; droplet-vitrification; long-term conservation; PVS2 vitrification; V cryo-plate

\section{Introduction}

Stevia rebaudiana (Bertoni) is an herbaceous perennial plant of the Asteraceae family. Its leaves produce diterpene glycosides (stevioside and rebaudiosides), and as stevioside is 300hundred-fold sweeter than sucrose, it is deemed to be a good natural sugar substitute $[1,2]$. In addition to its sweetening properties, it has various medicinal properties and actions. For this reason, the Stevia plant is an extremely interesting crop for breeders who select varieties with high diterpene glycosides content as well as for propagators and the target market.

S. rebaudiana is a self-incompatible plant and one of its limiting factors for large-scale cultivation is its poor seed germination [3]. Moreover, plants from seed propagation have a great variability in growth, maturity, and non-uniform plants, with considerable variations in the sweetening level and composition [4,5]. The recent results suggest that seed germination and stem cutting are not cost effective methods for higher biomass production, while the micropropagation can be a promising technique [3].

In vitro conservation and cryopreservation are unconventional biotechnological tools to preserve selected and valuable lines of $S$. rebaudiana, also taking into account the problems relating to its propagation by seed $[2,3]$.

A protocol for in vitro conservation of $S$. rebaudiana under slow growth conditions and mass micropropagation after the storage period was developed by Zayova et al. [6], while the long-term storage, cryopreservation of shoot tips, was carried out using the vitrification method by Shatnawi et al. [7]. Cryopreservation allows the storage of plant material (i.e., seeds, shoot tips, dormant buds, zygotic, and somatic embryos and pollen) at ultra-low temperatures in liquid nitrogen $\left(\mathrm{LN} ;-196{ }^{\circ} \mathrm{C}\right)$ or in the vapour phase of $\mathrm{LN}$ 
$\left(-165^{\circ} \mathrm{C}\right.$ to $\left.-170{ }^{\circ} \mathrm{C}\right)[8]$ and it is becoming a widely practised method for the long-term storage of plant genetic resources [9-12]. An advantage of the cryopreservation is that plant germplasm can theoretically be kept indefinitely in very little space and at low cost, excluding the initial investment. Over the last 30 years, various cryopreservation techniques have been developed using conventional slow freezing methods [13-15] as well as several vitrification-based cryopreservation procedures (encapsulation-dehydration; vitrification; encapsulation-vitrification [16-18], and more recently, droplet-vitrification (DV) [19]. Two recent novel cryopreservation techniques have been identified and have resulted in V cryo-plate [20] and D cryo-plate [21]. The DV uses aluminum foil strips, while the most recent cryogenic procedure (D or V cryo-plate) uses aluminum cryo-plates.

The regrowth rate obtained in Stevia with the vitrification protocol by Shatnawi et al. [7] was $68 \%$. Continuous research and technological evolution have markedly improved the cryogenic methodologies, allowing to enhance the recovery percentage of the species, as has occurred over the years, for example, in Vitis spp. [22,23] and potato [24,25]. The aim of this study was to assess the efficiency of the novel procedures, Droplet-vitrification and V cryo-plate, in order to improve the $S$. rebaudiana cryopreservation protocol.

\section{Results}

\subsection{Evaluation Plant Vitrification Solution 2 (PVS2) Tolerance}

In this study, a preliminary experiment on apical shoot tips (AST) and axillary shoot tips (AxST) to evaluate the effect of exposure duration and optimize temperature of PVS2 treatment showed that exposure to PVS2 induced time-dependent regrowth in both of the explants assessed and that the temperature of the treatment can influence regrowth rates (Figure 1). After 28 days of culture, the best regrowth rates were obtained for the explants treated with PVS2 with exposure times ranging from $20 \mathrm{~min}$ to $60 \mathrm{~min}$ at $0{ }^{\circ} \mathrm{C}$, and similar trends were observed for AST and AxST. AST treated with PVS2 solution for $60 \mathrm{~min}$ at both temperatures had $90 \%$ regrowth (Figure 1a), while in the AxST, the regrowth was $90 \%$ at $0{ }^{\circ} \mathrm{C}$ and $85 \%$ at $25{ }^{\circ} \mathrm{C}$ (Figure $1 \mathrm{~b}$ ). PVS2 treatments markedly affected regrowth potential after $60 \mathrm{~min}$, when a significant drop was observed, suggesting a toxic response to longterm exposure to PVS2, furthermore regrowth was also affected by treatment temperature. As regards the longer exposure time $(120 \mathrm{~min})$, the regrowth AST decreased significantly up to $35 \%$ and $20 \%$ at $0^{\circ} \mathrm{C}$ and $25{ }^{\circ} \mathrm{C}$, respectively, while for AxST the regrowth was significantly lower, dropping to $5 \%$ at $25^{\circ} \mathrm{C}$.

In the two cryopreservation procedures described below, the PVS2 exposure times of 20,30 , and $60 \mathrm{~min}$ at $0{ }^{\circ} \mathrm{C}$ will be applied, given that longer incubation times and $25^{\circ} \mathrm{C}$ resulted in a low regrowth percentage even in explants without immersion into LN.

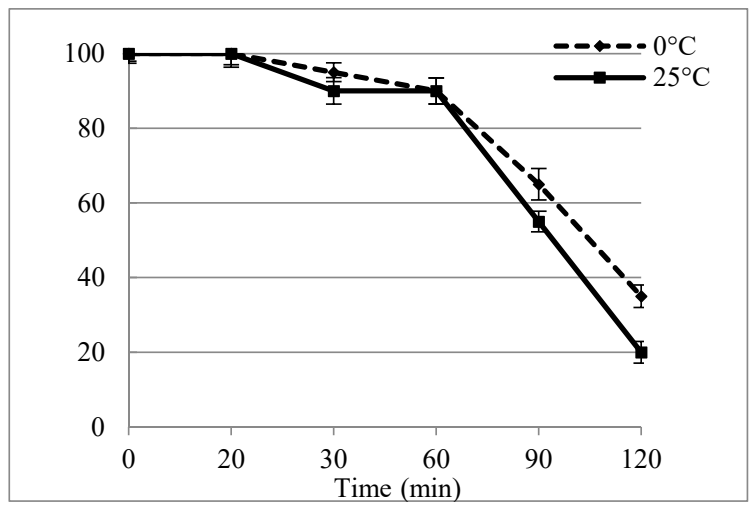

(a)

Figure 1. Cont. 


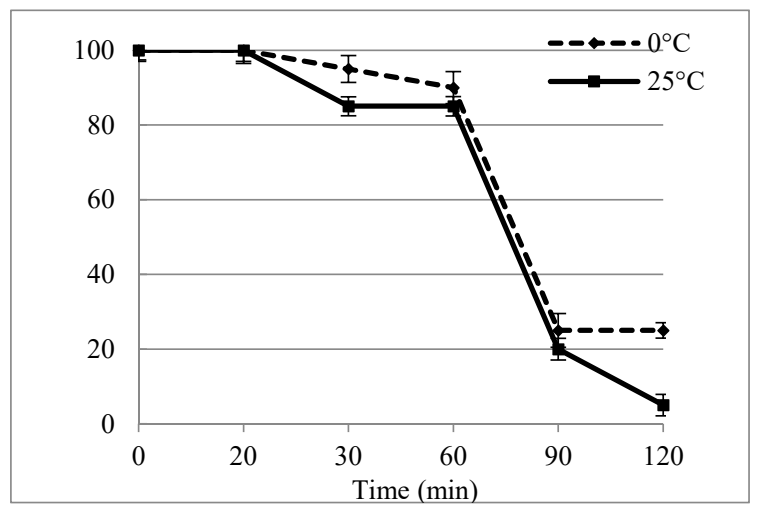

(b)

Figure 1. Effect of PVS2 treatment times on regrowth percentage $( \pm \mathrm{SD})$ of $S$. rebaudiana apical shoot tips (a) and axillary shoot tips (b) at $0{ }^{\circ} \mathrm{C}$ and $25^{\circ} \mathrm{C}$, after 28 days of culture.

\subsection{Droplet-Vitrification Procedure}

In the DV procedure, the effect of PVS2 treatment on the explants was more evident after immersion in LN and the survival and regrowth percentage of $S$. rebaudiana depended on PVS2 exposure time (Table 1). The survival rate was lower for all assessed exposure times to PVS2 compared to controls. The post-thaw survival percentages of the cryopreserved explants observed after seven days ranged from 6 to $87 \%$ for AST and 0 to $50 \%$ for AxST, while the best survival rate was observed for apical shoot tips treated with PVS2 for $60 \mathrm{~min}$ $(87 \%)$. As regards the axillary shoot tips, 30-min and 60-min PVS2 incubation times showed the same osmoprotection effect with 50\% survival rate. From the data collected, it is evident that 20 min PVS2 duration time was not osmoprotective for the explants, as none of the axillary shoot tips survived and only $6 \%$ of apical shoot tips survived, while no regrowth was observed after 28 days. Due to the lack of shoot development, this PVS2 time will not be considered for evaluating biometric parameters in the subculture. At the end of the experiment ( 28 days) the regrowth rate of the explants treated with PVS for $60 \mathrm{~min}$ remained high, confirming a better apical shoot regeneration response $(80 \%)$ with respect to axillary shoot tips (50\%). The explants that grew into normal shoots were used for the subculture evaluation described below.

Table 1. Droplet-vitrification procedure: effect of different PVS2 exposure times on survival and regrowth of apical shoot tips or axillary shoot tips after cryopreservation. Control (without any treatment).

\begin{tabular}{llllc}
\hline Treatment & \multicolumn{1}{c}{$\begin{array}{c}\text { 1 Survival Percentage } \\
\text { (7 days) }\end{array}$} & \multicolumn{2}{c}{$\begin{array}{c}\text { Regrowth Percentage } \\
\text { (28 days) }\end{array}$} \\
\hline & Apical Shoot Tips & Axillary Shoot Tips & Apical Shoot Tips & Axillary Shoot Tips \\
\hline Control & $100.0 \mathrm{a}$ & $93.0 \mathrm{a}$ & $93.0 \mathrm{a}$ & $93.0 \mathrm{a}$ \\
PVS2 20 min + LN & $6.0 \mathrm{c}$ & $0.0 \mathrm{c}$ & $0.0 \mathrm{~d}$ & $0.0 \mathrm{c}$ \\
PVS2 30 min + LN & $46.6 \mathrm{bc}$ & $50.0 \mathrm{~b}$ & $43.0 \mathrm{c}$ & $46.6 \mathrm{~b}$ \\
PVS2 60 min + LN & $87.0 \mathrm{ab}$ & $50.0 \mathrm{~b}$ & $80.0 \mathrm{ab}$ & $50.0 \mathrm{~b}$ \\
\hline
\end{tabular}

${ }^{1}$ Statistical analysis in each column was performed by ANOVA. Data followed by different letters are significantly different at $p \leq 0.05$ by Bonferroni's test.

Shoots derived from DV cryopreserved explants after the first subculture showed positive regrowth activity (Figure $2 \mathrm{~h}$ ), especially those obtained from initial explants treated with PVS2 + LN for $60 \mathrm{~min}$, which showed similar or slightly higher values to the control (Table 2). As regards the cryopreserved shoots treated with PVS2 $30+\mathrm{LN}$, several morphological parameters considered were significantly lower than the control group and the PVS2 $60+$ LN treatment. 
Table 2. First subculture after droplet-vitrification procedure: morphological parameters of S. rebaudiana shoots, from control and from cryopreserved apical shoot tips and axillary shoot tips. (Means $\pm \mathrm{SD}$ ).

\begin{tabular}{|c|c|c|c|c|c|c|}
\hline \multirow[t]{2}{*}{ Treatment } & \multicolumn{2}{|c|}{$\begin{array}{c}{ }^{1} \text { Shoot Length } \\
(\mathrm{cm})\end{array}$} & \multicolumn{2}{|c|}{$\begin{array}{c}\text { Shoots/Explants } \\
\left(n^{\circ}\right)\end{array}$} & \multicolumn{2}{|c|}{$\begin{array}{c}\text { Explants } \\
\text { with Shoot (\%) }\end{array}$} \\
\hline & $\begin{array}{c}\text { Apical } \\
\text { Shoot Tips }\end{array}$ & $\begin{array}{c}\text { Axillary } \\
\text { Shoot Tips }\end{array}$ & $\begin{array}{c}\text { Apical } \\
\text { Shoot Tips }\end{array}$ & $\begin{array}{c}\text { Axillary } \\
\text { Shoot Tips }\end{array}$ & $\begin{array}{c}\text { Apical } \\
\text { Shoot Tips }\end{array}$ & $\begin{array}{c}\text { Axillary } \\
\text { Shoot Tips }\end{array}$ \\
\hline Control & $4.30 \pm 0.48 \mathrm{ab}$ & $4.21 \pm 0.64 \mathrm{a}$ & $0.96 \pm 0.63 \mathrm{a}$ & $0.89 \pm 0.73 \mathrm{a}$ & $78.0 \mathrm{a}$ & $68.0 \mathrm{a}$ \\
\hline PVS2 $30 \mathrm{~min}+\mathrm{LN}$ & $4.00 \pm 0.39 \mathrm{~b}$ & $3.64 \pm 0.44 \mathrm{~b}$ & $0.84 \pm 0.55 a$ & $0.21 \pm 0.42 \mathrm{~b}$ & $77.0 \mathrm{a}$ & $21.0 \mathrm{~b}$ \\
\hline PVS2 $60 \mathrm{~min}+\mathrm{LN}$ & $4.90 \pm 0.44 \mathrm{a}$ & $4.03 \pm 0.39 \mathrm{ab}$ & $0.91 \pm 0.58 \mathrm{a}$ & $0.80 \pm 0.56 \mathrm{a}$ & $79.0 \mathrm{a}$ & $73.0 \mathrm{a}$ \\
\hline
\end{tabular}

${ }^{1}$ Statistical analysis in each column was performed by ANOVA. Data followed by different letters are significantly different at $p \leq 0.05$ by Bonferroni's test.
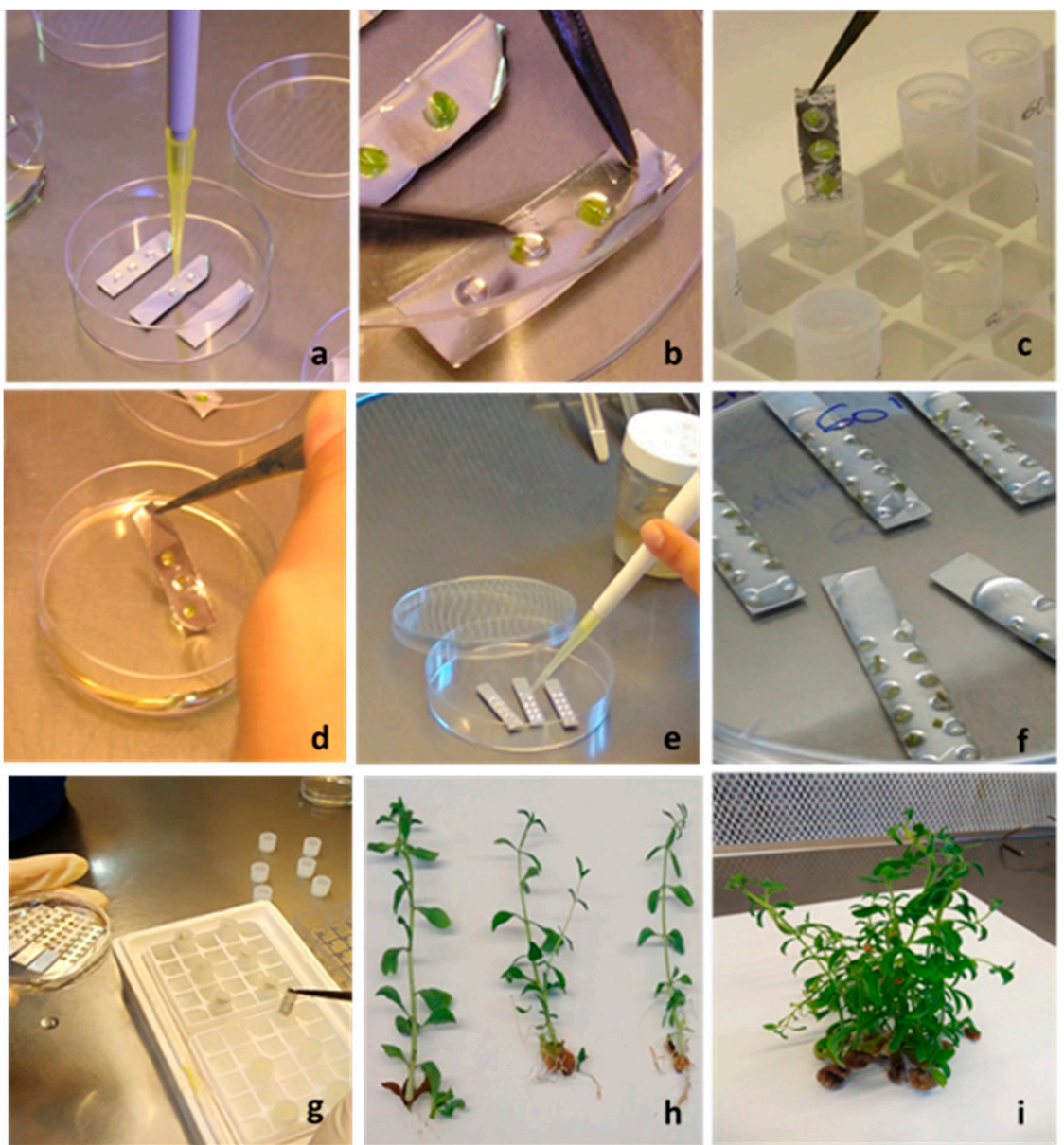

Figure 2. Some steps of droplet-vitrification and V cryo-plate cryopreservation procedures of Stevia rebaudiana. Droplet-vitrification: (a) PVS2 drops in aluminum foil; (b) explants placed into drops of PVS2; (c) aluminum foil strip with explants, plunged in cryovial filled with LN; (d) thawing of aluminum foil with explants in washing solution. V cryo-plate: (e) drops of sodium alginate in wells of cryo-plate; (f) explants into wells covered with calcium chloride solution; (g) cryo-plate, after PVS2 treatment, placed in cryovial filled with LN; (h) cryopreserved shoots with DV procedure after first subculture; (i) cryopreserved shoots with V cryo-plate procedure after second subculture.

\subsection{Cryo-Plate Procedure}

The $\mathrm{V}$ cryo-plate procedure proved to be effective for apical shoot tips and axillary shoot tips of $S$. rebaudiana. High viability was obtained except for the explants processed with PVS2 for $20 \mathrm{~min}$ followed by LN exposure. In Table 3 we reported the survival and regrowth percentages after 7 and 28 days of culture post thawing. AST gave the best 
response to the PVS2 treatments for cryopreservation while the AxST were more sensitive, showing lower survival and regrowth ability. In particular, treatment with PVS2 for $60 \mathrm{~min}$ provided better cryo-tolerance capability for the explants immersed in LN and showed the highest regrowth rate at 28 days of culture (93\% AST and 67\% AxST). Since minimal or no regrowth was observed from explants treated with PVS2 for $20 \mathrm{~min}+\mathrm{LN}$, this PVS2 time was not considered for evaluating biometric parameters in the subcultures.

In the first subculture, the shoots from cryopreserved AST showed a more active growth than the shoots from cryopreserved AxST (Table 4). Overall, no significant differences were observed among treatments and with the control, except for the shoot length in AST derived from PVS2 $30 \mathrm{~min}+\mathrm{LN}$, which had lower values. After 28 days all of the shoots were subcultured into fresh proliferation medium.

Table 3. V cryo-plate procedure: effect of different PVS2 exposure times on survival and regrowth of apical shoot tips or axillary shoot tips after cryopreservation. Control (without any treatment).

\begin{tabular}{|c|c|c|c|c|}
\hline \multirow[t]{2}{*}{ Treatment } & \multicolumn{2}{|c|}{$\begin{array}{c}{ }^{1} \text { Survival Percentage } \\
\text { (7 days) }\end{array}$} & \multicolumn{2}{|c|}{$\begin{array}{c}\text { Regrowth Percentage } \\
\text { (28 days) }\end{array}$} \\
\hline & Apical Shoot Tips & Axillary Shoot Tips & Apical Shoot Tips & Axillary Shoot Tips \\
\hline Control & $97.0 \mathrm{a}$ & $95.0 \mathrm{a}$ & $93.0 \mathrm{a}$ & $93.0 \mathrm{a}$ \\
\hline PVS2 $20 \mathrm{~min}+\mathrm{LN}$ & $10.0 \mathrm{~b}$ & $0.0 \mathrm{c}$ & $3.0 \mathrm{c}$ & $0.0 \mathrm{c}$ \\
\hline PVS2 $30 \mathrm{~min}+\mathrm{LN}$ & $87.0 \mathrm{a}$ & $64.0 \mathrm{~b}$ & $70.0 \mathrm{~b}$ & $46.0 \mathrm{~b}$ \\
\hline PVS2 $60 \mathrm{~min}+\mathrm{LN}$ & $93.0 \mathrm{a}$ & $69.0 \mathrm{~b}$ & $93.0 \mathrm{a}$ & $67.0 \mathrm{ab}$ \\
\hline
\end{tabular}

${ }^{1}$ Statistical analysis in each column was performed by ANOVA, Data followed by different letters are significantly different at $p \leq 0.05$ by Bonferroni's test.

Table 4. First subculture after V cryo-plate procedure: morphological parameters of S. rebaudiana shoots, from control and from cryopreserved apical shoot tips and axillary shoot tips. (Means $\pm \mathrm{SD}$ ).

\begin{tabular}{|c|c|c|c|c|c|c|}
\hline \multirow[t]{2}{*}{ Treatment } & \multicolumn{2}{|c|}{$\begin{array}{c}1 \text { Shoot Length } \\
(\mathrm{cm})\end{array}$} & \multicolumn{2}{|c|}{$\begin{array}{c}\text { Shoots/Explants } \\
\left(n^{\circ}\right)\end{array}$} & \multicolumn{2}{|c|}{$\begin{array}{c}\text { Explants } \\
\text { with Shoot (\%) }\end{array}$} \\
\hline & $\begin{array}{c}\text { Apical } \\
\text { Shoot Tips }\end{array}$ & $\begin{array}{c}\text { Axillary } \\
\text { Shoot Tips }\end{array}$ & $\begin{array}{c}\text { Apical } \\
\text { Shoot Tips }\end{array}$ & $\begin{array}{c}\text { Axillary } \\
\text { Shoot Tips }\end{array}$ & $\begin{array}{c}\text { Apical } \\
\text { Shoot Tips }\end{array}$ & $\begin{array}{c}\text { Axillary } \\
\text { Shoot Tips }\end{array}$ \\
\hline Control & $4.52 \pm 0.70 \mathrm{a}$ & $4.16 \pm 0.37 \mathrm{a}$ & $1.00 \pm 0.74 \mathrm{a}$ & $0.97 \pm 0.75 \mathrm{a}$ & $78.0 \mathrm{a}$ & $71.4 \mathrm{a}$ \\
\hline PVS2 $30 \mathrm{~min}+\mathrm{LN}$ & $4.00 \pm 0.51 \mathrm{~b}$ & $3.95 \pm 0.42 \mathrm{a}$ & $0.90 \pm 0.57 \mathrm{a}$ & $0.81 \pm 0.70 \mathrm{a}$ & $77.0 \mathrm{a}$ & $66.6 \mathrm{a}$ \\
\hline PVS2 $60 \mathrm{~min}+\mathrm{LN}$ & $4.37 \pm 0.78 \mathrm{a}$ & $4.20 \pm 0.48 \mathrm{a}$ & $0.93 \pm 0.60 \mathrm{a}$ & $0.73 \pm 0.52 \mathrm{a}$ & $78.6 \mathrm{a}$ & $70.0 \mathrm{a}$ \\
\hline
\end{tabular}

${ }^{1}$ Statistical analysis in each column was performed by ANOVA. Data followed by different letters are significantly different at $p \leq 0.05$ by Bonferroni's test.

During the second subculture, the differences between the V cryo-plate cryopreserved shoots derived from AST and AxST explants incubated in both PVS2 treatments disappeared, for all of the observed parameters (Table 5). However, it is evident that the shoots from AST treated for $30 \mathrm{~min}$ and $60 \mathrm{~min}+\mathrm{LN}$, even if not significantly different, were longer and produced a greater number of shoots per explant than those of the control, showing good multiplication capacity (Figure 2i).

Table 5. Second subculture after V cryo-plate procedure: morphological parameters of S. rebaudiana shoots, from control and from cryopreserved apical shoot tips and axillary shoot tips. (Means $\pm \mathrm{SD}$ ).

\begin{tabular}{lcccccc}
\hline Treatment & \multicolumn{2}{c}{$\begin{array}{c}\text { Shoot Length } \\
(\mathbf{c m})\end{array}$} & \multicolumn{2}{c}{$\begin{array}{c}\text { Shoots/Explants } \\
\left(\mathbf{n}^{\circ}\right)\end{array}$} & \multicolumn{2}{c}{$\begin{array}{c}\text { Explants } \\
\text { with Shoot (\%) }\end{array}$} \\
& $\begin{array}{c}\text { Apical } \\
\text { Shoot Tips }\end{array}$ & $\begin{array}{c}\text { Axillary } \\
\text { Shoot Tips }\end{array}$ & $\begin{array}{c}\text { Apical } \\
\text { Shoot Tips }\end{array}$ & $\begin{array}{c}\text { Axillary } \\
\text { Shoot Tips }\end{array}$ & $\begin{array}{c}\text { Apical } \\
\text { Shoot Tips }\end{array}$ & $\begin{array}{c}\text { Axillary } \\
\text { Shoot Tips }\end{array}$ \\
\hline Control & $6.69 \pm 0.98 \mathrm{a}$ & $6.52 \pm 0.88 \mathrm{a}$ & $1.50 \pm 0.68 \mathrm{a}$ & $1.43 \pm 0.81 \mathrm{a}$ & $100.0 \mathrm{a}$ & $93.3 \mathrm{a}$ \\
PVS2 30 min + LN & $7.19 \pm 1.00 \mathrm{a}$ & $6.43 \pm 1.10 \mathrm{a}$ & $1.53 \pm 0.81 \mathrm{a}$ & $1.40 \pm 0.81 \mathrm{a}$ & $96.6 \mathrm{a}$ & $83.0 \mathrm{a}$ \\
PVS2 60 min + LN & $7.21 \pm 1.40 \mathrm{a}$ & $6.44 \pm 1.50 \mathrm{a}$ & $1.56 \pm 0.96 \mathrm{a}$ & $1.40 \pm 0.96 \mathrm{a}$ & $93.3 \mathrm{a}$ & $83.0 \mathrm{a}$ \\
\hline
\end{tabular}

\footnotetext{
${ }^{1}$ Statistical analysis in each column was performed by ANOVA, Data followed by same letters indicate no significant difference at $p \leq 0.05$
} by Bonferroni's test. 
In this study, phenotype biometric examination during in vitro subcultures, in both DV and V cryo-plate, did not reveal any morphological abnormalities compared with the control plants.

\section{Discussion}

In recent years, various biotechnological approaches have been used for conserving endangered and medicinal species, providing conservation of pathogen free plant and biodiversity. Their preservation is essential for plant breeding programs, for maintaining biodiversity, and for utilization as resource of compounds to the medicinal, food, and crop protection industries [26].

A protocol for in vitro conservation of $S$. rebaudiana under slow growth conditions and mass micropropagation after six months of storage without subculturing, was developed by Zayova et al. [6], while cryopreservation to enable the long-term storage of shoot tips was carried out using a vitrification method [7]. Several innovative procedures have recently been implemented for cryopreservation in order to improve the explant physiological state, pre-treatment conditions, time and conditions of the cryoprotectant treatments, increase the cooling and warming rates, and the recovery medium to achieve successful regrowth [12,27-30]. Droplet-vitrification and V cryo-plate are the recent cryogenic procedures available and, in this study, both methods have been applied and evaluated on S. rebaudiana apical shoot tips and axillary shoot tips.

In order to implement an efficient cryopreservation protocol, it is essential that plant cells can be cooled in LN and recovered without causing cell damage to maintain the cell viability. The main cause of cell injury is the transition of water into ice crystals during the cooling process [31]. To avoid the formation of ice crystals, cells and tissues have to be adequately dehydrated and/or exposed to cryoprotectant solutions, before immersing them in LN. PVS2 is the most widely used cryoprotectant solution with successful on vitrification-based cryopreservation. It is also vital to carefully control dehydration step and prevent injury by chemical toxicity or excessive osmotic stress during PVS treatment. Possible toxic effects of the PVS2 and potential damage that may occur during vitrification were studied in various species [32-34]. Our findings suggest that $90 \mathrm{~min}$ and $120 \mathrm{~min}$ of PVS2 treatment, both at $0{ }^{\circ} \mathrm{C}$ and $25^{\circ} \mathrm{C}$, adversely affected the $S$. rebaudiana explants, which led to a significant decrease in the apical shoot tips regrowth percentage and axillary shoot tips, thus demonstrating that explants do not tolerate prolonged exposure to this solution. While short exposure duration to PVS2 $(20 \mathrm{~min})$ was ineffective in achieving osmoprotection on the tissues; $30 \mathrm{~min}$ and $60 \mathrm{~min}$ at $0{ }^{\circ} \mathrm{C}$ proved to be the best treatments for achieving satisfactory regrowth of shoots tips and nodal segments following both DV and V cryo-plate procedures. This is in line with the results reported for shoot tips of S. rebaudiana, which showed $68 \%$ of regrowth when subjected to the PVS2 solution for $60 \mathrm{~min}$ at $0{ }^{\circ} \mathrm{C}$ using a vitrification technique [7] and is also in accordance with the results obtained for other species. For example, the optimal PVS2 treatment time for Clinopodium odorum shoot tip cryopreservation was $60 \mathrm{~min}$ at $0^{\circ} \mathrm{C}$ using the $\mathrm{V}$ cryo-plate procedure [35]. However, the exposure time of the samples must be optimized for each species to assure tissue protection, e.g., the optimal exposure time to PVS2 at $0{ }^{\circ} \mathrm{C}$ was $30 \mathrm{~min}$ for blackberry apices and between $10 \mathrm{~min}$ and $30 \mathrm{~min}$ for cherry plums shoot tips [36], while in Limonium serotinum shoot tip regeneration was highest after PVS2 treatment for $30 \mathrm{~min}$ at $0{ }^{\circ} \mathrm{C}$ [37]. For two potato cultivars cryopreserved by the droplet-vitrification procedure, exposure to PVS2 for $40 \mathrm{~min}$ and $50 \mathrm{~min}$ at $0{ }^{\circ} \mathrm{C}$ gave the highest recovery rates, moreover apical buds responded better than axillary buds [38]. Irrespective of the vitrification solution used, the exposure time and temperature condition are fundamental and must be accurately determined depending on the plant material since some solutions can be toxic and even slight changes in treatment duration can have a dramatic impact on recovery [19].

The type of explant selected is also an important parameter for successful plant cryopreservation, in addition to size, cellular composition, physiological state and growth phase, which increase the probability of a positive response to various treatments before 
immersion in LN [9]. According to our cryopreservation data analysis, it seems that cryopreservation conditions proved to be more suitable for Stevia apical shoot tips than for axillary shoot tips. AST response is better for regrowth and in vitro subcultures, especially when a PVS2 exposure period of $60 \mathrm{~min}+\mathrm{LN}$ was applied. The PVS2-treated AST had a better osmoprotective effect respect to AxST, both in DV (80\% and 50\%, respectively) and in V cryo-plate, (93\% and 67\%). In additional, it also showed the higher sensitivity of AxST compared to AST.

The DV procedure [19] is a method obtained by combining the vitrification procedure with the droplet-freezing technique developed by Kartha et al. [39] in which explants are placed in minuscule droplets of vitrification solution on aluminium foil strips, whereas the $\mathrm{V}$ cryo-plate procedure $[20,40]$ combines the encapsulation and droplet-vitrification techniques, in which explants are placed on an aluminium cryo-plate and embedded in a thin layer of calcium alginate gel.

The two cryopreservation techniques (DV and V cryo-plate), applied on S. rebaudiana explants share the common trait of achieving higher cooling and warming rates compared to other vitrification-based procedures, because the explants placed on aluminium foils or cryo-plates, which are materials with high thermal conductivity, come into direct contact with liquid nitrogen during cooling and with the washing solution during warming [41]. Ultra-rapid cooling is more easily achieved using aluminium foil strips or aluminium cryo-plates rather than cryovials for immersing the explants directly into liquid nitrogen. These upgrades, combined with the optimal PVS2 exposure time, increased the chances of achieving a vitrified state during freezing in Stevia, resulting in superior regrowth after cryopreservation using the DV and V cryo-plate methods compared to results obtained by Shatnawi et coll. [7].

With respect to previous cryogenic methodologies, the simplicity is among the main advantages of using DV, moreover the technique can be successfully replicated by the technical staff [23]. The $\mathrm{V}$ cryo-plate method appears to be very systematic and time saving [42]. Both procedures appear highly promising to use large scale.

The DV method was initially used for potato shoot tip cryopreservation [43], but only a few years later its potential usefulness compared to other cryopreservation techniques was reported for several species such as in Musa [44], Rosa spp. [45-47], potato [25,48], taro [49], Lilium [50], Saccharum spp. [51], Thymus spp. [34], Mentha spp. [52], and Vitis spp. $[29,53,54]$. According to our results, applying this method to Stevia, shoot regrowth percentages of $80 \%$ and $50 \%$ were observed for cryopreserved AST and AxST, respectively. Panis et al. [44] reported that in eight different genomic groups of Musa spp., dropletvitrification procedure increased regrowth by $23-46 \%$ compared to standard vitrification. In our study this procedure resulted in an improvement of $23 \%$ compared to the traditional vitrification method used by Shatnawi et al. [7] considering apical shoot tips as explants. By histological observations conducted on cryopreserved potato and pineapple shoot tips, some authors $[55,56]$, concluded that droplet-vitrification caused the least injury to the tissues, thus it led to a benefit, increasing the recovery of cryopreserved shoot tips.

The application of $\mathrm{V}$ cryo-plate method has been reported for a wide range of species: strawberry [40], Dalmatian chrysanthemum [20], mint [42], mulberry [57], carnation [58], blueberry [59], mat rush [60], and sugarcane [61]. The satisfactory regrowth rates of cryopreserved potato shoot tips (96.7\%) in V cryo-plate proved that it is a useful strategy for preserving valuable potato germplasm [62]. Recently, the V cryo-plate method has been successfully applied to grapevine germplasm [63].

Some authors have reported that the cryo-plate method is a user-friendly procedure that minimizes the risk of shoot injury, and permits high and rapid cooling and warming rates of treated materials, which improves recovery [21,59,64,65]. One of the various advantages of using the $\mathrm{V}$ cryo-plate procedure is that the explants are attached to the cryo-plates in alginate gel during the whole procedure, including thawing. Handling the explants throughout the procedure is very quick and easy because only the cryo-plates are 
manipulated, therefore all laboratory personnel can carry out this procedure once they are practiced at mounting the explants on the cryo-plates [20].

The V cryo-plate procedure increased the effectiveness of cryopreservation for S. rebaudiana, thus resulting in superior regrowth, 93\% in AST and 67\% in AxST, compared to the vitrification procedure used by Shatnawi et al. [7], who obtained a $68 \%$ shoot regrowth rate. Moreover, the growth of the shoots recovered from $\mathrm{V}$ cryo-plate procedure, during the subcultures was very dynamic and some evaluated parameters were slightly higher than the control group, especially for shoots from AST treated with PVS2 + LN for 60 min. However, after the second subculture, no significant differences were observed between the explant types tested and the control shoots, thus proving the effectiveness of the procedure.

In conclusion, Stevia responded well to conservation in LN and applying innovative approaches enabled us to increase the regrowth rate following cryopreservation, using both DV and V cryo-plate. It demonstrated that these techniques are efficient for the long-term storage of $S$. rebaudiana.

\section{Materials and Methods}

\subsection{Plant Material and Culture Conditions}

S. rebaudiana shoots ( $4-5 \mathrm{~cm}$ in length) were cultured on $100 \mathrm{~mL}$ of Murashige and Skoog (MS) [66] medium with $1 \mathrm{mg} \mathrm{L}^{-1}$ indole-3-butyric acid (IBA), $0.1 \mathrm{M}$ sucrose and $7 \mathrm{~g} \mathrm{~L}^{-1}$ plant agar, at $\mathrm{pH} 5.8$ in glass culture vessels $(500 \mathrm{~mL})$, with 20 shoots per vessel. The shoot cultures were maintained at $23 \pm 1{ }^{\circ} \mathrm{C}$ under a $16 \mathrm{~h}$ photoperiod $\left(40 \mu \mathrm{mol} \mathrm{m}{ }^{-2} \mathrm{~s}^{-1}\right)$. The shoots were subcultured monthly on fresh medium of the same composition (standard culture conditions).

\subsection{Cold Hardening of In Vitro Shoot Cultures and Explant Preculture}

S. rebaudiana shoot cultures $\left(\sim 4 \mathrm{~cm}\right.$ in length with leaves) were transferred to $4{ }^{\circ} \mathrm{C}$ in low intensity light $\left(25 \mu \mathrm{mol} \mathrm{m}{ }^{-2} \mathrm{~s}^{-1}\right) 7$ days after the last subculture and maintained in hardening for 2 weeks before conducting cryopreservation experiments. Following preconditioning, apical shoots tips and axillary shoot tips, (explants with size of $1 \mathrm{~mm}$ to $1.5 \mathrm{~mm}$ for DV and $1 \mathrm{~mm}$ to $1.5 \mathrm{~mm} \times 1 \mathrm{~mm}$ for $V$ cryo-plate), were excised aseptically and placed in Petri dishes $(9 \mathrm{~cm} \varnothing)$ containing hormone-free MS medium supplemented with $0.5 \mathrm{M}$ sucrose at $\mathrm{pH} 5.8$ and precultured for $48 \mathrm{~h}$ at $4{ }^{\circ} \mathrm{C}$ in darkness. Then, they were placed in loading solution (LS: MS liquid medium containing $2.0 \mathrm{M}$ glycerol and $0.4 \mathrm{M}$ sucrose at $\mathrm{pH}$ 5.8) [67] for $20 \mathrm{~min}$ at room temperature.

\subsection{Evaluation of the Explant Tolerance to PVS2}

In order to evaluate the effect of exposure duration to PVS2 solution (PVS2 contains $0.4 \mathrm{M}$ sucrose, $30 \%(w / v)$ glycerol, $15 \%(w / v)$ ethylene glycol and $15 \%(w / v)$ dimethylsulfoxide in liquid MS medium, at $\mathrm{pH}$ 5.8) [17], the explants were incubated on sterilized PVS2 for $20,30,60,90$, or $120 \mathrm{~min}$ at $0^{\circ} \mathrm{C}$ and $25^{\circ} \mathrm{C}$. The explants were then rinsed with Washing Solution (WS: liquid MS medium, containing $1.2 \mathrm{M}$ sucrose [17] at $25^{\circ} \mathrm{C}$ for $20 \mathrm{~min}$ and plated on proliferation medium (MS medium with $1 \mathrm{mg}$ IBA, $0.1 \mathrm{M}$ sucrose, $7 \mathrm{~g} \mathrm{~L}^{-1}$ plant agar, $\mathrm{pH}$ 5.8) for recovery under standard conditions.

\subsection{Cryopreservation of S. rebaudiana Explants}

The DV and V cryo-plate procedures were applied to the apical shoot tips and axillary shoot tips of $S$. rebaudiana (Figure 2).

\subsubsection{Droplet-Vitrification (DV) Procedure}

The apical shoot tips (AST) and axillary shoot tips (AxST) were kept in LS at room temperature for $20 \mathrm{~min}$ and then placed into droplets of PVS2 (4 $\mu \mathrm{L}$ to $5 \mu \mathrm{L}$; each drop containing one explant) on sterilised aluminium foil strips $(\sim 6 \mathrm{~mm} \times 25 \mathrm{~mm}$, Figure 2a,b) in an open Petri dish at $0{ }^{\circ} \mathrm{C}$ and maintained under these conditions for 20, 30, or $60 \mathrm{~min}$. Following PVS2 exposure, the aluminium foil strips with the explants were immersed 
into $2 \mathrm{~mL}$ Nalgene ${ }^{\circledR}$ cryovials filled with liquid nitrogen (Figure 2c) and then plunged into $\mathrm{LN}$ for at least $1 \mathrm{~h}$. For thawing, the frozen aluminium foils were removed from the cryovial and immersed immediately into Washing Solution at room temperature for 20 min (Figure 2d). Explants were placed on hormone-free MS and kept in the dark for at $22 \pm 1{ }^{\circ} \mathrm{C}$ for $24 \mathrm{~h}$ and then transferred to standard culture conditions for recovery. The control group was composed of explants without any treatment.

\subsubsection{Cryo-Plate Procedure}

The aluminium cryo-plates $(7 \mathrm{~mm} \times 37 \mathrm{~mm} \times 0.5 \mathrm{~mm})$ with 12 wells $(\varnothing 1.5 \mathrm{~mm}$, depth $0.75 \mathrm{~mm}$ ) were used. Droplets of approximately $2 \mu \mathrm{L}$ of sodium alginate solution (the solution contains $2 \%(w / v)$ sodium alginate (Carlo Erba, Cornaredo, Milan, Italy; medium viscosity) in calcium-free MS basal medium with $0.4 \mathrm{M}$ sucrose, at $\mathrm{pH}$ 5.8) were poured into the cryo-plate wells (Figure 2e). The explants were placed individually into each well with a scalpel blade and fully immersed in one drop of sodium alginate solution (Figure 2f). The calcium chloride solution ( $0.1 \mathrm{M}$ calcium chloride in MS medium with $0.4 \mathrm{M}$ sucrose, at $\mathrm{pH}$ 5.8) was poured dropwise onto the section of the cryo-plates until the explants were covered and then left for $15 \mathrm{~min}$ to achieve complete polymerization. The excess calcium solution was removed by sucking it with a micropipette. The cryo-plates with explants were placed in LS for $20 \mathrm{~min}$ at room temperature, the LS was then removed and the cryo-plates were filled with PVS 2 for 20,30, 60, min at $0{ }^{\circ} \mathrm{C}$. After each PVS2 treatment, the cryo-plates were transferred into $2 \mathrm{~mL} \mathrm{Nalgene}{ }^{\circledR}$ cryovials placed in LN (Figure 2g), and then plunged directly into $\mathrm{LN}$ for at least $1 \mathrm{~h}$. The cryo-plates with cryopreserved explants were thawed by immersing them in $2 \mathrm{~mL}$ of WS solution for $15 \mathrm{~min}$. For recovery, the explants were placed on MS proliferation medium, in the dark for $24 \mathrm{~h}$ and then transferred to the light conditions described above. The control group was composed of explants without any treatment.

\subsection{Data Collection and Statistical Analysis}

In order to evaluate PVS2 incubation times, the explant regrowth percentage was determined 4 weeks after the treatments, while for cryopreservation experiments, postthaw survival rate data (i.e., percentage of explants that maintained their green colour and vigour) were recorded 7 days after transfer to proliferation medium, and the regrowth rate (the percentage of explants forming shoots $\geq 1 \mathrm{~cm}$ ) was recorded after 28 days. Each experimental treatment was replicated three times with each replication containing 10 shoot tips and nodal segments in the DV procedure and with 10 shoot tips and 15 nodal segments in the $\mathrm{V}$ cryo-plate procedure. For both procedures the following biometric parameters were recorded from regenerated cryopreserved shoots after the first subculture (28 days): (i) mean number of shoots, (ii) mean shoot length, and (iii) percentage of explants with shoots. In $\mathrm{V}$ cryo-plate procedure the biometric observations also involved the second subculture (28 days) with 3 replicates, 10 explants per each replicate. The data collected were subjected to one-way analysis of variance (ANOVA) followed by the Bonferroni post hoc test to determine the significance level between means at $95 \%$ confidence level $(p \leq 0.05)$. The percentage data were transformed in Arcsine before applying one-way ANOVA. The data were statistically analyzed using Statgraphics Centurion XVI (Stat Point, Inc., Herndon, VA, USA).

Author Contributions: Conceptualization, C.B.; methodology, C.B., L.S.O.C.; investigation, L.S.O.C., S.E.m.; resources, C.B.; data curation, R.P.; writing—original draft preparation, C.B.; writing-review and editing, R.P., C.B.; project administration, C.B.; All authors have read and agreed to the published version of the manuscript.

Funding: This research received no external funding.

Institutional Review Board Statement: Not applicable.

Informed Consent Statement: Not applicable. 
Data Availability Statement: The data presented in this study are available on request from the corresponding author.

Conflicts of Interest: The authors declare no conflict of interest.

\section{References}

1. Lemus-Mondaca, R.; Vega-Gálvez, A.; Zura-Bravo, L.; Ah-Hen, K. Stevia rebaudiana Bertoni, source of a high-potency natural sweetener: A comprehensive review on the biochemical, nutritional and functional aspects. Food Chem. 2012, 132, 1121-1132. [CrossRef] [PubMed]

2. Yadav, A.K.; Singh, S.; Dhyani, D.; Ahuja, P.S. A review on the improvement of stevia [Stevia rebaudiana (Bertoni)]. Can. J. Plant Sci. 2011, 91, 1-27. [CrossRef]

3. Khalil, S.A.; Zamir, R.; Ahmad, N. Selection of suitable propagation method for consistent plantlets production in Stevia rebau-diana (Bertoni). Saudi J. Biol. Sci. 2014, 21, 566-573. [CrossRef] [PubMed]

4. Nakamura, S.; Tamura, Y. Variation in the main glycosides of Stevia (Stevia rebaudiana Bertoni). Jpn. J. Trop. Agric. 1985, 29, 109-116. [CrossRef]

5. Sivaram, L.; Mukundan, U. In vitro culture studies on Stevia rebaudiana. Vitr. Cell. Dev. Biol. Anim. 2003, 39, 520-523. [CrossRef]

6. Zayova, E.; Nedev, T.; Dimitrova, L. In vitro storage of Stevia rebaudiana Bertoni under slow growth conditions and mass multiplication after storage. Bio Bull. 2017, 3, 30-38.

7. Shatnawi, M.A.; Shibli, R.A.; Abu-Romman, S.M.; Al-Mazra, M.S.; Al Ajlouni, Z.I.; Shatanawi, A.; Odeh, W.H. Clonal prop-agation and cryogenic storage of the medicinal plant Stevia rebaudiana. Span. J. Agricul. Res. 2011, 1, 213-220. [CrossRef]

8. Reed, B.M. Cryopreservation-Practical Considerations. In Plant Cryopreservation: A Practical Guide; Reed, B.M., Ed.; Springer: New York, NY, USA, 2008; pp. 3-13.

9. Niino, T. Developments in plant genetic resources cryopreservation technologies. In Effective Genebank Management in APEC Member Economies; Jung-Hoon, K., Ed.; NIAB: Suwon, Korea, 2006; pp. 197-217.

10. Wang, M.-R.; Lambardi, M.; Engelmann, F.; Pathirana, R.; Panis, B.; Volk, G.M.; Wang, Q.-C. Advances in cryopreservation of in vitro-derived propagules: Technologies and explant sources. Plant Cell Tissue Organ Cult. (PCTOC) 2021, 144, 7-20. [CrossRef]

11. Panis, B. Sixty years of plant cryopreservation: From freezing hardy mulberry twigs to establishing reference crop collections for future generations. Acta Hortic. 2019, 1234, 1-8. [CrossRef]

12. Benelli, C.; De Carlo, A.; Engelmann, F. Recent advances in the cryopreservation of shoot-derived germplasm of economically important fruit trees of Actinidia, Diospyros, Malus, Olea, Prunus, Pyrus and Vitis. Biotechnol. Adv. 2013, 31, 175-185. [CrossRef]

13. Withers, L.A.; Engelmann, F. In vitro Conservatipon of Plant Genetic Resources. In Biotechnology in Agriculture; Altman, A., Ed.; Marcel Dekker Inc.: New York, NY, USA, 1998; pp. 57-88.

14. Reed, B.M.; Uchendu, E. Controlled Rate Cooling. In Plant Cryopreservation: A Practical Guide; Reed, B.M., Ed.; Springer: New York, NY, USA, 2008; pp. 77-92.

15. Engelmann, F. Importance of Cryopreservation for the Conservation of Plant Genetic Resources. In Cryopreservation of Tropical Plant Germplasm: Current Research Progress and Application; Engelmann, F., Takagi, H., Eds.; Japan International Research Center for Agricultura: Tsukuba, Japan; International Plant Genetic Resources Institute: Rome, Italy, 2000; pp. 8-20.

16. Ono, M.; Baak, S.J. Revisiting the J-Curve for Japan. Mod. Econ. 2014, 5, 32-47. [CrossRef]

17. Sakai, A.; Kobayashi, S.; Oiyama, I. Cryopreservation of nucellar cells of navel orange (Citrus sinensis Osb. var. brasiliensis Tanaka) by vitrification. Plant Cell Rep. 1990, 9, 30-33. [CrossRef] [PubMed]

18. Kartha, K.K.; Engelmann, F. Cryopreservation and Germplasm Storage. In Plant Cell and Tissue Culture; Vasil, I.K., Thorpe, T.A., Eds.; Kluwer Press: Dordrecht, Germany, 1994; pp. 195-230.

19. Sakai, A.; Engelmann, F. Vitrification, encapsulation-vitrification and droplet-vitrification: A review. CryoLetters 2007, 28, 151-172. [PubMed]

20. Yamamoto, S.; Rafique, T.; Priyantha, W.S.; Fukui, K.; Matsumoto, T.; Niino, T. Development of a cryopreservation procedure using aluminium cryo-plates. CryoLetters 2011, 3, 256-265.

21. Niino, T.; Yamamoto, S.; Fukui, K.; Castillo Martínez, C.R.; Arizaga, M.V.; Matsumoto, T.; Engelmann, F. Dehydration im-proves cryopreservation of mat rush (Juncus decipiens Nakai) basal stem buds on cryo-plates. CryoLetters 2013, 34, 549-560. [PubMed]

22. Matsumoto, T. Cryopreservation of axillary shoot tips of in vitro-grown grape (Vitis) by a two-step vitrification protocol. Euphytica 2003, 131, 299-304. [CrossRef]

23. Bettoni, J.C.; Kretzschmar, A.A.; Bonnart, R.; Shepherd, A.; Volk, G.M. Cryopreservation of 12 Vitis Species Using Apical Shoot Tips Derived from Plants Grown In vitro. HortScience 2019, 54, 976-981. [CrossRef]

24. Gonzalez-Arnao, M.T.; Panta, A.; Roca, W.M.; Escobar, R.H.; Engelmann, F. Development and large scale application of cryopreservation techniques for shoot and somatic embryo cultures of tropical crops. Plant Cell Tissue Organ Cult. (PCTOC) 2007, 92, 1-13. [CrossRef]

25. Niino, T.; Arizaga, M.V. Cryopreservation for preservation of potato genetic resources. Breed. Sci. 2015, 65, 41-52. [CrossRef]

26. Panis, B.; Lambardi, M. Status of cryopreservation technologies in plants (crops and forest trees). In The Role of Biotechnology in Exploring and Protecting Agricultural Genetic Resources; Ruane, J., Sonnino, A., Eds.; FAO: Rome, Italy, 2006; pp. 61-78. 
27. Mathew, L.; McLachlan, A.; Jibran, R.; Burritt, D.J.; Pathirana, R.N. Cold, antioxidant and osmotic pre-treatments maintain the structural integrity of meristematic cells and improve plant regeneration in cryopreserved kiwifruit shoot tips. Protoplasma 2018, 255, 1065-1077. [CrossRef]

28. Marković, Z.; Chatelet, P.; Preiner, D.; Sylvestre, I.; Kontić, J.K.; Engelmann, F. Effect of shooting medium and source of material on grapevine (Vitis vinifera L.) shoot tip recovery after cryopreservation. CryoLetters 2014, 35, 40-47. [PubMed]

29. Bettoni, J.C.; Bonnart, R.; Volk, G.M. Challenges in implementing plant shoot tip cryopreservation technologies. Plant Cell Tissue Organ Cult. (PCTOC) 2021, 144, 21-34. [CrossRef]

30. Volk, G.M.; Harris, J.L.; Rotindo, K.E. Survival of mint shoot tips after exposure to cryoprotectant solution components. Cryobiology 2006, 52, 305-308. [CrossRef] [PubMed]

31. Fuller, B.J. Cryoprotectants: The essential antifreezes to protect life in the frozen state. CryoLetters 2004, 25, 375-388. [PubMed]

32. Towill, L.E.; Bonnart, R. Cracking in a vitrification solution during cooling or warming does not effect growth of cryo-preserved mint shoot tips. CryoLetters 2003, 24, 341-346. [PubMed]

33. Volk, G.M.; Walters, C. Plant vitrification solution 2 lowers water content and alters freezing behavior in shoot tips during cryoprotection. Cryobiology 2006, 52, 48-61. [CrossRef]

34. Ozudogru, E.A.; Kaya, E. Cryopreservation of Thymus cariensis and T. vulgaris shoot tips: Comparison of three vitrification-based methods. CryoLetters 2012, 33, 363-375. [PubMed]

35. Engelmann-Sylvestre, I.; Engelmann, F. Cryopreservation of in vitro-grown shoot tips of Clinopodium odorum using aluminium cryo-plates. Vitr. Cell. Dev. Biol. Anim. 2015, 51, 185-191. [CrossRef]

36. Vujović, T.; Sylvestre, I.; Ružić, D.; Engelmann, F. Droplet-vitrification of apical shoot tips of Rubus fruticosus L. and Prunus cerasifera Ehrh. Sci. Hortic. 2011, 130, 222-228. [CrossRef]

37. Barraco, G.; Sylvestre, I.; Iapichino, G.; Engelmann, F. Cryopreservation of Limonium serotinum apical meristems from in vitro plantlets using droplet-vitrification. Sci. Hortic. 2011, 130, 309-313. [CrossRef]

38. Panta, A.; Panis, B.; Ynouye, C.; Swennew, R.; Roca, W. Development of a PVS2 droplet vitrification method for potato cryopreservation. CryoLetters 2014, 35, 255-266. [PubMed]

39. Kartha, K.K.; Leung, N.L.; Mroginski, L.A. In vitro growth responses and plant regeneration from cryopreserved meristems of cassava (Manihot esculenta Crantz). Z. Pflanzenphysiol. 1982, 107, 133-140. [CrossRef]

40. Yamamoto, S.; Fukui, K.; Rafique, T.; Khan, N.I.; Castillo Martinez, C.R.; Sekizawa, K.; Matsumoto, T.; Niino, T. Cryopreservation of in vitro-grown shoot tips of strawberry by the vitrification method using aluminium cryo-plates. Plant Genet. Resour. 2012, 10, 14-19. [CrossRef]

41. Engelmann, F. Cryopreservation of Clonal Crops: A Review of Key Parameters. Acta Hortic. 2014, 1039, 31-39. [CrossRef]

42. Yamamoto, S.; Rafique, T.; Fukui, K.; Sekizawa, K.; Niino, T. V-cryo-plate procedure as an effective protocol for cryobanks: Case study of mint cryopreservation. CryoLetters 2012, 33, 12-23. [PubMed]

43. Schäfer-Menuhr, A.; Schumacher, H.M.; Mix-Wagner, G. Cryopreservation of Potato Cultivars-Design of a Method for Routine Application in Genebanks. Acta Hortic. 1997, 447, 477-482. [CrossRef]

44. Panis, B.; Piette, B.M.A.G.; Swennen, R. Droplet vitrification of apical meristems: A cryopreservation protocol applicable to all Musaceae. Plant Sci. 2005, 168, 45-55. [CrossRef]

45. Halmagyi, A.; Pinker, I. Plant regeneration from Rosa shoot tips cryopreserved by a combined droplet vitrification method. Plant Cell Tissue Organ Cult. (PCTOC) 2006, 84, 145-153. [CrossRef]

46. Pawłowska, B.; Szewczyk-Taranek, B. Droplet vitrification cryopreservation of Rosa canina and Rosa rubiginosa using shoot tips from in situ plants. Sci. Hortic. 2014, 168, 151-156. [CrossRef]

47. Le Bras, C.; Le Besnerais, P.-H.; Hamama, L.; Grapin, A. Cryopreservation of ex-vitro-grown Rosa chinensis 'Old Blush' buds using droplet-vitrification and encapsulation-dehydration. Plant Cell Tissue Organ Cult. (PCTOC) 2013, 116, 235-242. [CrossRef]

48. Kim, H.H.; Yoon, J.W.; Park, Y.E.; Cho, E.G.; Sohn, J.K.; Kim, T.S.; Engelmann, F. Cryopreservation of potato cultivated va-rieties and wild species: Critical factors in droplet vitrification. CryoLetters 2006, 27, 223-234. [PubMed]

49. Sant, R.; Panis, B.; Taylor, M.; Tyagi, A. Cryopreservation of shoot-tips by droplet vitrification applicable to all taro (Colocasia esculenta var. esculenta) accessions. Plant Cell Tissue Organ Cult. (PCTOC) 2007, 92, 107-111. [CrossRef]

50. Chen, X.-L.; Li, J.-H.; Xin, X.; Zhang, Z.-E.; Xin, P.-P.; Lu, X.-X. Cryopreservation of in vitro-grown apical meristems of Lilium by droplet-vitrification. S. Afr. J. Bot. 2011, 77, 397-403. [CrossRef]

51. Kaya, E.; Souza, F.V.D. Comparison of two PVS2-based procedures for cryopreservation of commercial sugarcane (Saccharum spp.) germplasm and confirmation of genetic stability after cryopreservation using ISSR markers. Vitr. Cell. Dev. Biol.-Anim. 2017, 53, 410-417. [CrossRef]

52. Senula, A.; Keller, E.R.J.; Sanduijav, T.; Yohannes, T. Cryopreservation of cold-acclimated mint (Mentha spp.) shoot tips using a simple vitrification protocol. CryoLetters 2007, 28, 1-12.

53. Bi, W.-L.; Hao, X.-Y.; Cui, Z.-H.; Volk, G.M.; Wang, Q. Droplet-vitrification cryopreservation of in vitro-grown shoot tips of grapevine (Vitis spp.). Vitr. Cell. Dev. Biol.-Anim. 2018, 54, 590-599. [CrossRef]

54. Volk, G.M.; Shepherd, A.N.; Bonnart, R. Successful Cryopreservation of Vitis Shoot Tips: Novel Pre-treatment Combinations Applied to Nine Species. CryoLetters 2019, 39, 322-330. 
55. Wang, B.; Li, J.-W.; Zhang, Z.; Wang, R.-R.; Ma, Y.-L.; Blystad, D.-R.; Keller, E.J.; Wang, Q.-C. Three vitrification-based cryopreservation procedures cause different cryo-injuries to potato shoot tips while all maintain genetic integrity in regenerants. J. Biotechnol. 2014, 184, 47-55. [CrossRef]

56. Souza, F.V.D.; Kaya, E.; Vieira, L.D.J.; De Souza, E.H.; Amorim, V.B.D.O.; Skogerboe, D.; Matsumoto, T.; Alves, A.A.C.; Ledo, C.A.D.S.; Jenderek, M.M. Droplet-vitrification and morphohistological studies of cryopreserved shoot tips of cultivated and wild pineapple genotypes. Plant Cell Tissue Organ Cult. (PCTOC) 2015, 124, 351-360. [CrossRef]

57. Yamamoto, S.; Rafique, T.; Sekizawa, K.; Koyama, A.; Ichihashi, T.; Niino, T. Development of an effective cryopreservation protocol using aluminum cryo-plates for in vitro-grown shoot tips of mulberries (Morus spp.) originated from the tropics and subtropics. Sanshi Konchu Biotec (J. Insect Biotech. Sericology) 2012, 81, 57-62.

58. Sekizawa, K.; Yamamoto, S.-I.; Rafique, T.; Fukui, K.; Niino, T. Cryopreservation of in vitro-grown shoot tips of carnation (Dianthus caryophyllus L.) by vitrification method using aluminium cryo-plates. Plant Biotechnol. 2011, 28, 401-405. [CrossRef]

59. Matsumoto, T.; Yamamoto, S.; Fukui, K.; Niino, T. Cryopreservation of blueberry dormant shoot tips using V cryo-plate method. HortScience 2014, 49, S337-S338.

60. Niino, T.; Watanabe, K.; Nohara, N.; Rafique, T.; Yamamoto, S.-I.; Fukui, K.; Arizaga, M.V.; Martinez, C.R.C.; Matsumoto, T.; Engelmann, F.; et al. Cryopreservation of mat rush lateral buds by air dehydration using aluminum cryo-plate. Plant Biotechnol. 2014, 31, 281-287. [CrossRef]

61. Rafique, T.; Yamamoto, S.I.; Fukui, K.; Mahmood, Z.; Niino, T. Cryopreservation of sugarcane using the V cryo-plate technique. CryoLetters 2015, 36, 51-59. [PubMed]

62. Yamamoto, S.-I.; Wunna; Rafique, T.; Arizaga, M.V.; Fukui, K.; Gutierrez, E.J.C.; Martinez, C.R.C.; Watanabe, K.; Niino, T. The Aluminum Cryo-plate Increases Efficiency of Cryopreservation Protocols for Potato Shoot Tips. Am. J. Potato Res. 2015, 92, 250-257. [CrossRef]

63. Bettoni, J.C.; Bonnart, R.; Shepherd, A.N.; Kretzschmar, A.A.; Volk, G.M. Modifications to a Vitis Shoot Tip Cryopreservation Procedure: Effect of Shoot Tip Size and Use of Cryoplates. CryoLetters 2019, 40, 103-112.

64. Salma, M.; Fki, L.; Engelmann-Sylvestre, I.; Niino, T.; Engelmann, F. Comparison of droplet-vitrification and D-cryoplate for cryopreservation of date palm (Phoenix dactylifera L.) polyembryonic masses. Sci. Hortic. 2014, 179, 91-97. [CrossRef]

65. Matsumoto, T.; Yamamoto, S.-I.; Fukui, K.; Rafique, T.; Engelmann, F.; Niino, T. Cryopreservation of Persimmon Shoot Tips from Dormant Buds Using the D Cryo-plate Technique. Hortic. J. 2015, 84, 106-110. [CrossRef]

66. Murashige, T.; Skoog, F. A Revised Medium for Rapid Growth and Bio Assays with Tobacco Tissue Cultures. Physiol. Plant. 1962, 15, 473-497. [CrossRef]

67. Matsumoto, T.; Sakai, A.; Yamada, K. Cryopreservation of in vitro-grown apical meristems of wasabi (Wasabia japonica) by vitrification and subsequent high plant regeneration. Plant Cell Rep. 1994, 13, 442-446. [CrossRef] 